\title{
PRODUÇÃO E CONFIGURAÇÃO DE CONDOMÍNIOS FECHADOS HORIZONTAIS NA CIDADE DE BELÉM- PARÁ, BRASIL, DÉCADAS DE 1990 E 2000
}

\author{
PRODUCCIÓN Y CONFIGURACIÓN DE CONDOMINIOS CERRADOS HORIZONTALES EN LA CIUDAD DE \\ BELÉM, DECADAS 1990 Y 2000
}

\section{PRODUCTION AND CONFIGURATION OF SINGLE-FAMILY HOUSES CLOSED CONDOMINIUMS BUILT IN IN BELÉM-PA, 1990's AND 2000's}

\section{RIOS, MARYLU FERNANDES GUEDES}

Mestre em Arquitetura e Urbanismo (UFPA); arquiteta UFPA/EBSERH; marylu_guedes@hotmail.com

\author{
LIMA, JOSÉ JÚLIO FERREIRA \\ PhD em Arquitetura; Universidade Federal do Pará; jjlimaufpa@gmail.com
}

\section{RESUMO}

A área de expansão de Belém (Pará, Brasil), em particular a Av. Augusto Montenegro, um de seus principais eixos viários, tem sido cenário de profundas transformações espaciais a partir da década de 1990 e, principalmente, nos anos 2000. A partir da criação de demanda por moradias fora do centro urbano houve forte influência do mercado imobiliário na disseminação do arranjo espacial segregado conhecido como "condomínio fechado horizontal". O presente estudo tem como objetivo a análise das condições socioeconômicas e de aspectos regulatórios que tornaram a execução deste "tipo" espacial, um produto compatível e potencial à expansão do capital imobiliário naquela área. Para tanto analisam-se a configuração urbanística e tipologias residenciais de três condomínios pioneiros no eixo viário mencionado, assim como são verificados os efeitos sobre eles de regulações federais e municipais e de regulações internas contidas em convenções condominiais. Ao final, são feitas correlações entre o desenho dos condomínios e o que é encontrado ou permitido na cidade aberta, mediante diretrizes vigentes da regulação urbana pública municipal.

PALAVRAS-CHAVE: condomínios fechados horizontais; área de expansão; configuração condominial; tipologias habitacionais; regulação urbanística.

\section{RESUMEN}

El área de expansión de Belém (Pará, Brasil), en particular la Av. Augusto Montenegro, una de sus carreteras principales, ha sido escenario de profundas transformaciones espaciales desde la década de 1990 y principalmente en la década de 2000. Desde la creación de demanda por parte del mercado inmobiliario, hubo una fuerte influencia del mercado inmobiliario en la difusión del arreglo espacial segregado "condominios cerrados horizontales" en el contexto urbano local. El presente estudio tiene como objetivo analizar las condiciones socioeconómicas y los aspectos regulatorios que hicieron que la ejecución de este "tipo" espacial sea un producto compatible y potencial para la supervivencia del capital inmobiliario en esa área. Con base en la verificación de las configuraciones urbanas y las tipologías residenciales de tres condominios pioneros en el eje de la Av. Augusto Montenegro, se verifican los efectos en estos arreglos de las regulaciones federales y municipales y las regulaciones internas contenidas en las convenciones de condominios. Al final, se hacen correlaciones entre el diseño de los condominios y lo que se encuentra 0 permite en la ciudad abierta, de acuerdo con las pautas actuales de la regulación urbana publica municipal.

PALABRAS CLAVES: condominios horizontales cerrados; área de expansión; configuración de condominio; tipologías de vivienda; regulación urbana.

\section{ABSTRACT}

The expansion area of Belém (Pará, Brazil), in particular Augusto Montenegro Avenue, one of its main road axes, has been a scenario of deep spatial transformations since the 1990's and mainly in the 2000's. The transformations were strongly influenced by the segregated spatial arrangement "horizontal closed condominiums" dissemination in local urban context. This study aims to analyze the socioeconomic conditions and regulatory aspects that contribute to lay out this spatial "type", considered to be a real estate asset compatible and potentially important for the real estate capital in that area. The urban configuration and residential typologies of three pioneer condominiums built along the axis of Augusto Montenegro avenue. For the purposes of the paper there is the assessment of federal and municipal regulations in the design of the arrangements, as well as the effects of internal regulations, called condominium conventions. At the end, there are correlations of the internal design of the condominiums and what is found or allowed in the open city, according to current municipal public urban regulation guidelines.

KEYWORDS: horizontal closed condominiums; urban expansion area; condominium configuration; housing typologies; urban regulations. 


\section{INTRODUÇÃO}

O presente estudo tem como objetivo analisar correlações entre a atuação do capital imobiliário e o marco regulatório urbanístico na construção de condomínios fechados horizontais em Belém-Pará (Brasil), no início dos anos 2000. O marco regulatório compreende regulações urbanísticas municipais de uso e ocupação do solo, assim como as normas internas contidas nas convenções condominiais de três condomínios fechados na área de expansão de Belém: Greenville I, Cidade Jardim I e Greenville Exclusive. Os três foram pioneiros na expansão da malha urbana e, apesar de estarem localizados próximos uns dos outros, às margens da Av. Augusto Montenegro, foram construídos em circunstâncias econômicas diferentes: em 1990, 2002 e 2006, respectivamente.

Figura 1: Mapa de Belém com os três condomínios estudados.

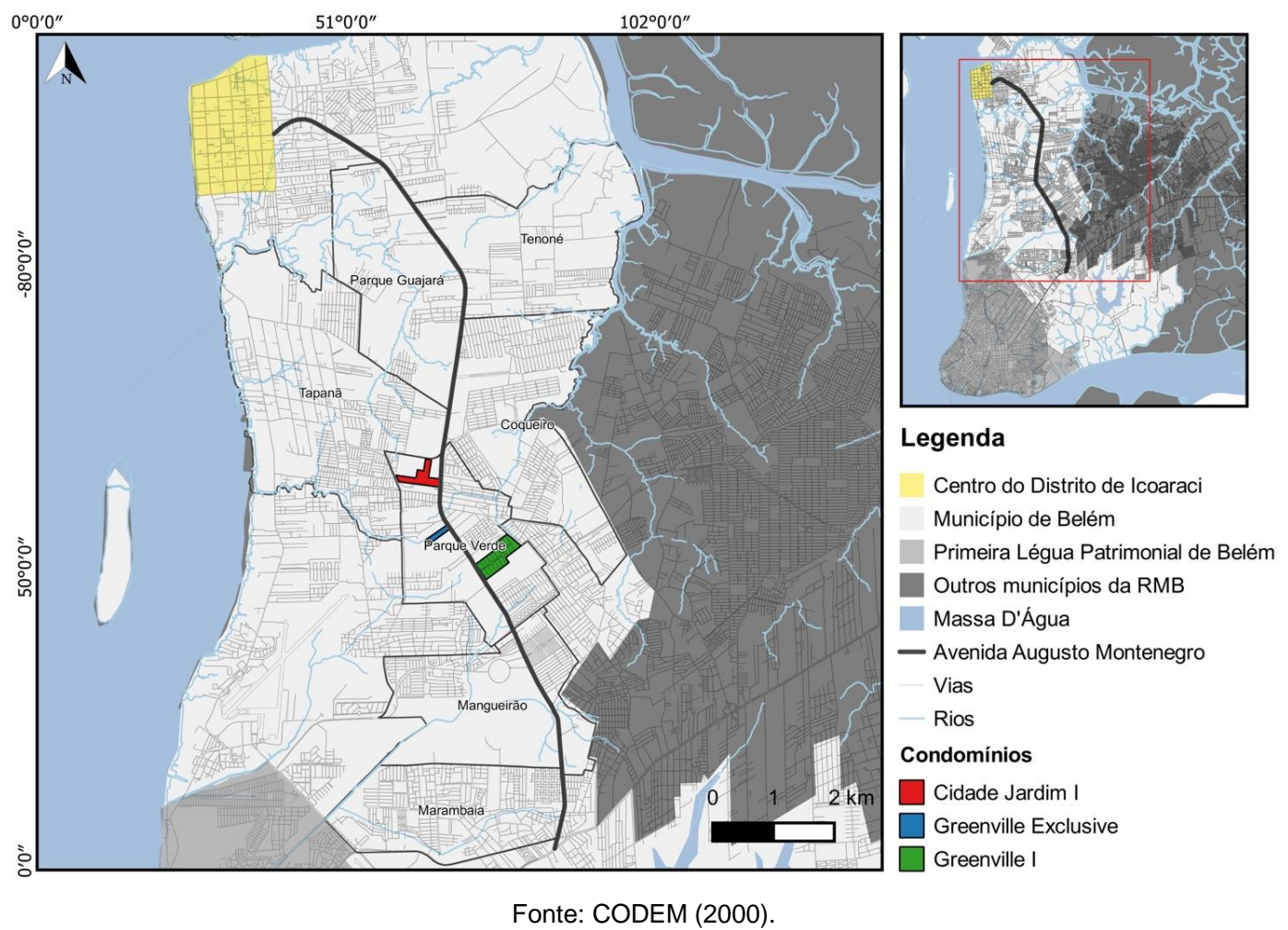

A ausência de legislação que trate da configuração de condomínios fechados horizontais gera certa permissividade jurídica aos incorporadores, permitindo o estabelecimento de regras e regulações próprias, com a aplicação parcial de leis pertinentes, delas utilizando o que convém à lógica econômica e do mercado imobiliário. As normas urbanísticas parecem não ser satisfatórias para regular condomínios fechados ou exclusivos. Sugere-se que a concepção projetual dos condomínios e das unidades habitacionais sofrem a influência dessa (des)regulação e que, mais do que isso, ignora aspectos relativos à regulação pública. Internamente, a administração condominial estabelece também critérios urbanísticos próprios, que vão desde a regulação de posturas até normas regimentais de uso e ocupação dos lotes, de forma análoga à lei municipal de uso e ocupação do solo e ao Código Civil.

Como abordagem metodológica adotada, a análise conduzida relaciona a espacialização do capital na configuração interna dos empreendimentos, por meio de parâmetros de uma possível racionalidade econômica dos arranjos urbanísticos, alcançada pelos incorporadores diante da conjuntura vigente à época de seus lançamentos, bem como de uma comparação com a ocupação urbana extramuros. Para tal, são verificados os resultados gerados pelas convenções nas casas condominiais, de modo que se busca estabelecer um perfil tipológico de potencial máximo edilício, e ainda uma correlação quanto à permissividade ou restritibilidade edilícia gerada, conforme definido pela legislação urbanística vigente na cidade aberta. Em relação à análise do que pode ser definido como racionalidade econômica dos empreendimentos, é aqui explorada através de indicadores capazes de relacionar componentes das regulações urbanísticas internas e a viabilidade financeira de cada empreendimento, considerando o momento em que foi lançado. Assim, serão utilizados três parâmetros, a saber: capilaridade, compacidade e permeabilidade.

A capilaridade é analisada através da relação dos quilômetros de via por hectare urbanizado de cada condomínio (MASCARÓ, 2005; SOUZA, 2013). Os resultados comparativos obtidos são inversamente 
proporcionais à racionalidade econômica alcançada pelo empreendedor, ou seja, quanto maior a capilaridade, menor a racionalidade. A compacidade edilícia dos empreendimentos é conhecida de forma proporcional à sua racionalidade econômica, relacionando o número de unidades habitacionais por hectare urbanizado de empreendimento (NETTO; SABOYA, 2010). A predominância de áreas verdes é investigada através do parâmetro permeabilidade, que se dá pela relação de hectares de área verde pelo hectare urbanizado do condomínio (SBARRA, 2018). Esta relação se dá também de forma inversamente proporcional à racionalidade econômica do empreendedor, de forma que o condomínio mais permeável é o menos racional economicamente.

A seção seguinte a esta introdução tem como foco o exame do cenário econômico vigente à época de lançamento dos condomínios na área de expansão de Belém. A análise documental de negociações de compra e venda das construtoras com seus primeiros compradores torna possível ponderar acerca das dificuldades e facilidades apresentadas ao público quando da aquisição do imóvel em cada período, a exemplo da existência ou não de financiamentos e parcelamentos bancários, dentre outras formas de negociação oportunas. A "criação" de demanda pelo próprio mercado imobiliário, dentre outros fatores, tem a influência do ordenamento jurídico que trata de limitações para loteamentos e condomínios, temática que é desenvolvida na terceira seção. Na quarta seção, os aspectos da economia e as regulações estudadas são articulados em análises dos arranjos urbanísticos dos condomínios fechados investigados. Nela, são investigados o dimensionamento, a configuração e a distribuição de lotes, edificações, quadras, vias e áreas condominiais. Por um lado, os estudos focam no desempenho ou eficiência econômica das tipologias, buscando correlacionar aspectos relativos à racionalização gerada pelo capital imobiliário na configuração interna destes condomínios, bem como nas tipologias de suas casas e os efeitos produzidos quanto a densidade e compacidade edilícia em relação ao encontrado no entorno de bairro.

\section{CENÁRIO ECONÔMICO VIGENTE NOS ANOS DE LANÇAMENTO DOS CONDOMÍNIOS}

Dentre outros fatores, a espacialização do capital na forma de condomínios fechados horizontais em Belém, como em outras cidades, foi moldada pelo momento econômico vivido à época de suas construções, na virada para o ano 2000. Na década de 1990, caracterizada por grande instabilidade política e econômica no país, buscavam-se caminhos contrários aos enormes índices inflacionários herdados da década anterior. Após o lançamento do Plano Cruzado, em 1986, o governo Sarney (1985-1990) utilizou-se do congelamento dos preços, como tentativa de contenção da inflação, que redundou em grande fracasso e "em pouco tempo os produtos mais básicos sumiram das prateleiras dos supermercados” (MELO, 2009, p. 3). Em 1989, a inflação brasileira atingia assombrosos $84,32 \%$ ao mês, com a sensação de colapso político-econômico e administrativo, através de inúmeras denúncias de corrupção, além de inflação de quatro dígitos que, segundo o Almanaque da Folha daquele mesmo ano, atingia o percentual anual de 1.037,56\%. Em 1990, o governo Collor adotou medidas bastante impopulares como tentativa de "liquidar o leão inflacionário". O Plano Collor bloqueou poupanças e contas correntes, congelando preços e salários. Apesar de todo o sacrifício imposto à sociedade, os resultados foram frustrantes e, em 1992, a inflação acumulada foi de $1.158,00 \%$, que culminaram com o impeachment do presidente.

O Condomínio Greenville I foi lançado na área de expansão da cidade de Belém, em 1990, em um mercado imobiliário "enfraquecido", que encontrou na classe de alta renda o "combustível" para sua sobrevivência em meio ao cenário econômico acima referido. Os altos índices inflacionários tinham papel preponderante na já péssima distribuição de renda e desigualdade social existente no país, de forma que as classes detentoras de capital, através de ganhos especulativos em meio aos percentuais inflacionários sobre suas rendas acumuladas, eram capazes de fazer movimentar o desaquecido mercado imobiliário da época. Naquele momento, tanto a infraestrutura condominial quanto as obras residenciais do Condomínio Greenville I foram realizadas pelo regime de administração, de forma que o capital era injetado de acordo com a disponibilidade financeira dos proprietários, e por isso demandavam um tempo de execução mais longo.

As negociações eram feitas através da venda de lotes vazios, mediante parcelamentos financeiros tratados diretamente com a construtora, que executava a infraestrutura interna do condomínio paulatinamente, à medida que as parcelas de seus compradores iam sendo liquidadas. Os valores médios de lotes já quitados, segundo análise de certidão de registro em cartório de um proprietário, em janeiro de 1994, por exemplo, chegavam a valores aproximados a $\mathrm{CR} \$ 9.000 .000,00$ (Nove milhões de cruzeiros reais), que, convertidos ao padrão monetário atual, equivaleriam a $R \$ 3.200,00$ (Três mil e duzentos reais) em média. Como resultado espacial, o Condomínio Greenville I primou por grandes lotes $(15 \mathrm{~m} \times 32 \mathrm{~m})$, grande extensão de área verde e expressiva arborização, itens muito valorizados pelos futuros proprietários como símbolos de status e qualidade de vida, tendo ainda sua localização favorecida por uma infraestrutura preexistente na área. 
O mandato "tampão" de Itamar Franco, vice de Fernando Collor, a partir do final de 1992, tomou como vital para o país a resolução da questão inflacionária. Conforme reflexões de Melo (2009, p. 3), a "inflação e a desorganização econômica não apenas causavam paralisia econômica, atraso e desigualdade social, mas já se mostrava mesmo disfuncional do ponto de vista político". Após várias tentativas de condução da economia, Itamar nomeia Fernando Henrique Cardoso (FHC) como ministro da Fazenda, que, juntamente a um grupo de economistas, buscava uma solução de combate à inflação e assim de recondução econômica do país. A mudança de rumos é iniciada em 1994, com a criação da Unidade Real de Valor (URV), equivalente em fevereiro a $\operatorname{Cr} \$ 2.750,00$, e o subsequente lançamento do Plano Real em julho daquele mesmo ano.

Tratou-se, neste momento, de mudanças estruturais e constitucionais que contaram com a articulação de vários mecanismos de Estado com o objetivo único de combate à inflação. Observou-se a reestruturação do sistema financeiro nacional, que acabou por provocar a privatização de vários bancos estaduais e a liquidação ou incorporação de bancos privados. Nos anos seguintes, a Lei de responsabilidade fiscal assinalou profunda transformação no país (MELO, 2009). Com o tempo, o plano Real foi se consolidando e gerando um clima de euforia no país, trazendo consigo a abertura do mercado brasileiro a produtos importados através da manutenção do dólar a valores paritários, o que gerou um cenário político favorável à eleição de FHC como presidente da República, em 1994. A inflação que ainda apresentava índices alarmantes em 1994 (1.093,8\%), conforme dados, foi reduzida substancialmente para $14,7 \%$ em 1995, consolidando-se a partir de então com apenas um dígito: 9,3\%, em 1996; 7,4\%, em 1997; e 1,7\%, em 1998.

No setor imobiliário, observou-se grande dificuldade na ampliação de financiamentos a longo prazo devido às altas taxas de juros e ao mau desempenho da economia sobre os rendimentos de pessoa física. Conforme expressam Cardoso e Jaenisch (2017, p. 4), órgãos representativos do setor, como a Câmara Brasileira da Indústria da Construção (CBIC), Associação de Dirigentes de Empresas do Mercado Imobiliário (ADEMI) e Sindicato da Indústria da Construção Civil (SINDUSCON), passam a sugerir a reestruturação de modelos de financiamento baseados "no modelo norte-americano de securitização, que pretendiam regulamentar o mercado secundário de hipotecas e estabelecer mecanismos que dessem suporte à financeirização das atividades do setor imobiliário".

Nascia assim, em 1997, o Sistema de Financiamento Imobiliário (SFI), criado num contexto de forte restrição ao crédito, gerado tanto pela alta taxa de juros vigente, quanto pelo controle exercido pelo capital financeiro sobre os recursos dos fundos destinados ao financiamento imobiliário Sistema Brasileiro de Poupança e Empréstimo (SBPE) e Fundo de Garantia do Tempo de Serviço (FGTS). Apesar do SFI ter sido criado como forma de movimentar o setor, as regras que limitavam o acesso aos fundos da habitação permaneceram inalteradas (CARDOSO; JAENISCH, 2017).

Neste clima de grandes dificuldades econômicas, FHC foi reeleito como o candidato mais capaz de enfrentar a crise econômica naquele momento. O câmbio que antes se estabelecera como um dos pontos mais importantes para a estabilidade da moeda, passa a grande vilão capaz de abalar toda a estrutura econômica até então criada. Em 13 de janeiro de 1999, a moeda americana, enfim, dispara e flutua depois de uma desvalorização de $63 \%$, pondo fim a um ciclo de política econômica que gerou grande turbulência política no país, a partir de então direcionando a economia brasileira na busca por novos rumos. Setores importantes da economia, como a indústria e o mercado imobiliário, mantinham-se paralisados diante da crise cambial. Segundo dados da análise de Mattoso e Muniz (2006, p. 1) "a contribuição da construção civil ao PIB nacional sofreu quedas continuadas - de $9,1 \%$ para $6,5 \%$ - reflexo de uma retração média anual da produção de aproximadamente $3 \%$ ", apresentando ainda queda de unidades imobiliárias financiadas via Caixa Econômica Federal e SBPE.

O Condomínio Cidade Jardim I foi lançado em meados do ano 2002, com lotes comercializados no ano de seu lançamento por valores em torno de $\mathrm{R} \$ 18.000,00$, segundo anúncios publicitários da época. No entanto, pode-se ponderar que, pela sua boa localização e condições de acessibilidade, numa área já provida de infraestrutura de comércio e serviços e certa proximidade ao Condomínio Greenville I, teve importante acréscimo no preço de seus lotes, com valores que chegavam em média a $R \$ 29.000,00$ no ano de 2006 . A esta altura, no eixo de expansão de Belém representado pela Av. Augusto Montenegro, sua localização dispunha de três acessos de entrada ao condomínio por vias distintas, possibilitando a fluidez de tráfego de seus moradores para além do eixo da avenida. Apesar de lotes menores (em média $10 \mathrm{~m} \times 20 \mathrm{~m}$ ) e espaços comuns reduzidos, este condomínio contava com equipamentos de lazer que, segundo a publicidade feita na época, garantiriam a qualidade de vida de seus moradores. Dispunha ainda de 10 lotes comerciais em sua área frontal, voltados para o exterior e também para a população extramuros.

As negociações de compra e venda podiam ser feitas de duas formas: 1) através da venda de lotes vazios, com a quitação de parcelas pelo comprador diretamente com a construtora; ou 2) através da venda de lotes já com suas casas construídas, que funcionava como um sistema de consórcio criado pela própria construtora. Neste caso, os adquirentes teriam a execução das casas em seus lotes priorizada pela construtora, através 
de sorteios ou antecipação de parcelas. Com o passar dos anos e com o incremento de políticas econômicas nacionais de financiamento habitacional, as negociações passaram a ser feitas com financiamento imobiliário de até 180 meses, via Caixa Econômica Federal (CEF). A partir de então destaca-se o atendimento à nova lógica do mercado imobiliário, que começava a espacializar seu capital de forma acelerada em empreendimentos na área de expansão urbana.

Luís Inácio Lula da Silva assume a presidência do Brasil em 2003. De acordo com os dados obtidos em Curado (2011), entre os anos de 2003 e 2008, a taxa média de expansão do PIB foi da ordem de 4,2\% a.a., quase o dobro se comparado aos $2 \%$ observados no período compreendido entre os anos 1995 e 2005. Este cenário de recuperação do crescimento é caracterizado principalmente pela melhoria nos indicadores de renda e redução da pobreza, apesar de a política econômica de forma geral ter-se mantido basicamente com o mesmo "arranjo macroeconômico definido na segunda gestão de FHC, ou seja, manteve o tripé metas de inflação, regime de câmbio flutuante com intervenção (dirty floating em inglês) e ajuste fiscal" (CURADO, 2011, p. 94).

Quanto à situação do mercado imobiliário, é possível perceber já no primeiro ano do governo Lula um direcionamento para a adoção de medidas que buscavam expandir o financiamento habitacional. Entre essas medidas, segundo Cardoso e Jaenisch (2017), houve a revisão pelo Banco Central, da flexibilização dos critérios de exigibilidade então vigentes para os recursos do SBPE, estimulando os agentes financeiros a buscarem o investimento imobiliário e a revisão dos critérios de investimento habitacional pelo Conselho Curador do FGTS, ampliando a oferta para setores de renda mais baixa e concentrando o crédito em imóveis novos (resolução 460-2004).

Além dessas medidas, houve mudanças institucionais que buscavam suprimir da legislação tudo o que representasse risco ao investimento privado no setor, com destaque para a Lei 10.931 de 2004, que instituiu o patrimônio de afetação, criando mecanismos de segurança do empreendimento em caso de falência da construtora; e a alienação fiduciária, herança do governo anterior, que permitia a apropriação do bem pelo banco credor como forma de garantia do financiamento (COSTA, 2010). Foram criados ainda novos instrumentos financeiros como forma de fortalecimento do SFI, a exemplo da ampliação do apoio dos fundos públicos, como o FGTS, e do direcionamento dos recursos da poupança ao setor habitacional, gerando crédito tanto para pessoa física como para pessoas jurídicas, via retomada do mercado de capitais. Conforme avaliam Mattoso e Muniz (2006, p. 1), mudanças importantes foram introduzidas na Caixa, que se tornaria o principal agente público para o setor imobiliário, com a "criação de novos produtos, redução dos juros, aumento dos prazos, aperfeiçoamento dos sistemas de risco, simplificação dos processos de contratação, aumento do volume de recursos próprios para a habitação e a realização dos 'Feirões da Casa Própria', agora também realizado pelo setor privado".

Como resultado, o crédito foi garantido para o financiamento de unidades habitacionais novas para os setores de renda média e também ampliou a oferta de crédito via FGTS para setores de renda até 3 salários mínimos. Vale ressaltar que "esse boom foi financiado fundamentalmente através de mecanismos tradicionais de financiamento - o Sistema Financeiro de Habitação (SFH)" (CARDOSO; JAENISCH, 2017, p. 6). Diante do novo cenário econômico nacional apresentado, o capital imobiliário local passou a direcionar e intensificar seus esforços na construção de condomínios fechados horizontais agora voltados ao atendimento das classes médias. Diante desse contexto, o Condomínio Greenville Exclusive foi lançado em 2006, direcionado ao público de camadas de média renda. Com a expansão do financiamento via SFI às pessoas jurídicas, este mecanismo foi adotado não só pelos compradores de seus lotes e casas, como também pela construtora na aquisição da gleba em que foi construído o Condomínio, sendo os lotes negociados com as casas já totalmente construídas, tomando aproximadamente dois anos para sua completa execução. Conforme análise de documentos de averbação em cartório de uma casa térrea, observam-se valores de custo de execução da construtora em torno de $\mathrm{R} \$ 60.000,00$, em 2008 , com posterior venda no mesmo ano aos adquirentes no valor aproximado de $\mathrm{R} \$ 166.000,00$, mantendo o imóvel até então sob alienação fiduciária, com financiamento em 180 parcelas mensais de sua fração majoritária por banco privado. Como sua localização já era provida de infraestrutura básica, manteve-se a lógica de mercado de redução de lotes (10m x $21 \mathrm{~m}$ ), áreas comuns viárias e verdes, pela própria dimensão reduzida da gleba e a diversidade de itens de lazer.

\section{REGULAÇÕES URBANISTICAS E EDILICIAS INCIDENTES SOBRE OS PROJETOS DE CONDOMINIIOS FECHADOS HORIZONTAIS: LACUNAS, CONFLITOS E DISTORÇÕES}

Tanto em termos do loteamento interno quanto nos seus entornos, o arranjo espacial gerado pelo que denominados hoje condomínios fechados horizontais tem encontrado contradições e falhas jurídicas importantes, quando da aplicação de regulações urbanísticas. A inexistência de legislação que trate exclusivamente de condomínios fechados horizontais e a possível permissividade jurídica gerada pelos 
incorporadores fazem com que se estabeleçam regras e (des)regulações próprias, extraindo das leis pertinentes apenas o que é conveniente à lógica econômica do capital imobiliário.

Por se tratar de empreendimentos imobiliários que têm como pressuposto a criação de um ente legal, aos condomínios fechados incide a Lei 4591, de 16 de dezembro de 1964, a chamada Lei do Condomínio (BRASIL, 1964). A princípio e como essência, pôde-se verificar sua obrigatoriedade pela natureza econômica das ações de incorporadores, de proteção mútua ao negócio, condôminos e à incorporação em si, e aos que estão envolvidos no empreendimento como construtores e corretores de imóveis. Incide ainda a Lei 6766, de 19 de dezembro de 1979, a chamada Lei de Parcelamento do Solo, que visa a regular o parcelamento do solo para fins urbanos, definindo conceitos para loteamento, desmembramento e remembramento, mas principalmente definindo diretrizes de ação a construtores bem como limitações de uso do solo nos loteamentos. Por seu caráter público, merece destaque a determinação de um percentual da gleba loteada a ser destinado a áreas públicas, definidas como sistemas de circulação, implantação de equipamento urbano e comunitário, bem como a espaços livres de uso público:

Parágrafo 1: A percentagem de áreas públicas prevista no inciso I deste artigo não poderá ser inferior a $35 \%$ (trinta e cinco por cento) da gleba, salvo nos loteamentos destinados ao uso industrial cujos lotes forem maiores do que $15.000 \mathrm{~m}^{2}$ (quinze mil metros quadrados), caso em que a percentagem poderá ser reduzida (BRASIL, 1979).

Posteriormente, a Lei oํ 9.785, de 1999 altera este parágrafo, dando poderes à legislação municipal:

Parágrafo 1:: A legislação municipal definirá, para cada zona em que se divida o território do Município, os usos permitidos e os índices urbanísticos de parcelamento e ocupação do solo, que incluirão, obrigatoriamente, as áreas mínimas e máximas de lotes e os coeficientes máximos de aproveitamento (BRASIL, 1999).

A referida lei define dimensões básicas e regula ainda questões ambientais e a sustentabilidade do habitat urbano:

Art. 4: Os loteamentos deverão atender, pelo menos, aos seguintes requisitos:

II - os lotes terão área mínima de $125 \mathrm{~m}^{2}$ (cento e vinte e cinco metros quadrados) e frente mínima de 5 (cinco) metros, salvo quando o loteamento se destinar a urbanização específica ou edificação de conjuntos habitacionais de interesse social, previamente aprovados pelos órgãos públicos competentes;

III - ao longo das águas correntes e dormentes e das faixas de domínio público das rodovias e ferrovias, será obrigatória a reserva de uma faixa não-edificável de 15 (quinze) metros de cada lado, salvo maiores exigências da legislação específica (BRASIL, 1979).

Posteriormente, a lei 13.465, de 2017, traz novidades ao artigo 4 ㅇ e $5^{\circ}$ da lei $6766 / 79$, citando o termo "condomínio de lotes" e abrindo uma incipiente discussão sobre o assunto, até então nunca abordado no ordenamento jurídico. Vale ressaltar que este marco jurídico foi o que constou no registro de grande parte de condomínios fechados horizontais de grandes extensões na década de 1990, tratando-se de uma lei de finalidade pública, mas utilizada de forma distorcida e indevida para o registro de construção de loteamentos privados. Tais determinações têm sido utilizadas de forma explícita ou implícita na elaboração de projetos de loteamentos, quer sejam posteriormente transformados em condomínios fechados quer não. As previsões de áreas públicas e a definição de tamanhos de lotes, bem como as medidas de proteção ambiental são os principais critérios definidores de uma densidade construtiva bruta, depois transformada, por meio do arranjo urbanístico, em densidade edilícia em cada empreendimento. Estabelece-se, assim, a base regulatória para submissão aos órgãos urbanísticos fiscalizadores, bem como o elo de ligação entre o projeto e a cadeia econômica da viabilidade financeira de cada empreendimento. Apesar de serem registrados como loteamentos, os condomínios fechados consistem em glebas loteadas, arruadas e providas de infraestrutura, que, depois de registradas conforme os ditames da lei 6766, são cercadas por muros, cerca elétrica, equipamentos de monitoramento e segurança $24 \mathrm{~h}$, além de uma portaria que a partir de então controlará a permissão de entrada e saída de seus circulantes.

O Condomínio Greenville I foi o pioneiro dos condomínios fechados horizontais na Av. Augusto Montenegro, sendo lançado em 1990, apesar de o registro de sua convenção ser datado somente de 1994. O artigo 3ํㅓㅇ de seu Estatuto Social sugere que, ao ser denominado Loteamento Greenville Residence, teve como base jurídica de criação a Lei 6766/79. Porém, no mesmo artigo, refere-se à forma de "condomínio fechado". De fato, após o lançamento do que seria um loteamento, o mesmo foi murado e transformou-se num condomínio fechado horizontal de alto padrão, adotando para fins legais os dispositivos da Lei 4591/64 quanto à gestão condominial. No caso, com a peculiaridade da formação de uma sociedade composta pelos proprietários dos terrenos, tendo os mesmos responsabilidades de garantir o caráter de "status social", conforme expresso no estatuto: 
PARÁGRAFO $6^{\circ} \mathrm{O}$ Associado se obriga a defender externamente o bom conceito do Condomínio GREENVILLE RESIDENCE I e se compromete a só tomar qualquer medida em juízo contra a Sociedade e/ou Condomínio após esgotados todos os recursos internos que tem direito (CONDOMÍNIO GREENVILLE I, 1994, não paginado).

De forma diferente do Condomínio Greenville I, registrado segundo os ditames da Lei do Loteamento, o Condomínio Cidade Jardim I foi registrado conforme a Lei 4591/64, de acordo com sua convenção condominial, datada de 2004 (CONDOMÍNIO CIDADE JARDIM I, 2004). Apesar da grande extensão da gleba - e contrariando o que vinha sendo utilizado quanto à legislação para registro de grandes extensões de terra, normalmente a 6766/79 -, o Condomínio Cidade Jardim I teve como forma de negociação a possibilidade da venda de lotes e casas separadamente, ou seja, o futuro proprietário tinha a liberdade de adquirir o lote vazio, invalidando o que dispõe sua lei base de criação, a 4591/64, que estabelece em seu art. $1^{\circ}$, citado acima, que lotes e edificações sejam administrados de forma indissociável pelo incorporador ou construtor até sua entrega final ao adquirente da unidade autônoma.

O registro em cartório do Condomínio Greenville Exclusive, de 2006, foi feito também segundo os ditames da lei $4591 / 64$ e, quanto à comercialização, contemplou o que prediz sua lei de registro, tendo seus lotes e edificações vendidos pelo incorporador e adquiridos de forma indissociável pelos proprietários (CONDOMÍNIO GREENVILLE EXCLUSIVE, 2006).

\section{ANÁLISE COMPARATIVA DOS ARRANJOS URBANÍSTICOS DOS CONDOMÍNIOS FECHADOS ESTUDADOS E DE UNIDADES HABITACIONAIS SOB A LUZ DE NORMAS URBANISTICAS E EDILÍCIAS}

O arranjo urbanístico do Condomínio Greenville I, longilíneo em relação ao acesso pela Av. Augusto Montenegro, define a tendência dos demais condomínios. O Quadro 1 mostra as características gerais dos três condomínios fechados estudados. A implantação de condomínios fechados como alternativa para residência de camadas de renda alta da população ocorre com a implantação de atrativos nas áreas condominiais, conforme verificado no Quadro 2. Além disso, merece destaque a existência de lotes nãoresidenciais - exceção feita ao Condomínio Greenville I, cujos lotes comerciais são internos; já os demais têm acesso externo aos condomínios.

Quadro 1: Características dos condomínios estudados.

\begin{tabular}{|c|c|c|c|}
\hline & GREENVILLE I & CIDADE JARDIM I & GREENVILLE EXCLUSIVE \\
\hline Planta de urbanização & 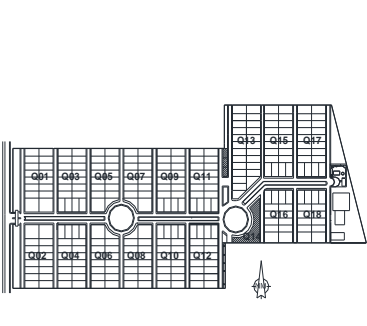 & 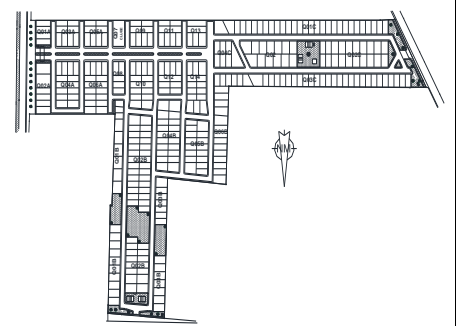 & 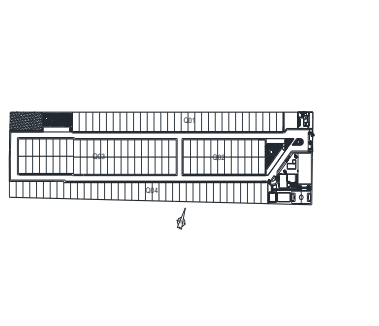 \\
\hline Área total & 22,911 hectares & 11,698 hectares & 4,806 hectares \\
\hline Área do(s) lotes(s) & $480,00 \mathrm{~m}^{2}$ & $180,00 \mathrm{~m}^{2} ; 200,00 \mathrm{~m}^{2} ; 237,50 \mathrm{~m}^{2}$ & $210,00 \mathrm{~m}^{2} ; 230,00 \mathrm{~m}^{2}$ \\
\hline Dimensões dos lotes & $15 \mathrm{~m} \times 32 \mathrm{~m}$ & $9 \mathrm{~m} \times 20 \mathrm{~m} ; 10 \mathrm{~m} \times 20 \mathrm{~m} ; 12,5 \mathrm{~m} \times 19 \mathrm{~m}$ & $10 \mathrm{~m} \times 21 \mathrm{~m} ; 10 \mathrm{~m} \times 23 \mathrm{~m}$ \\
\hline Área ocupada com lotes & 14,824 hectares & 6,974 hectares & 3,094 hectares \\
\hline Área de lazer & 1,445 hectares & 0,289 hectares & 0,516 hectares \\
\hline Área de com. e serv. & $2.122,28$ hectares & $2.746,40$ (acesso externo) & 440,00 (acesso externo) \\
\hline Área ocupada por vias & 3,163 hectares & 3,669 hectares & 1,112 hectares \\
\hline Área verde comum & 3,042 hectares & 0,844 hectares & 0,205 hectares \\
\hline Largura das vias & $7,00 \mathrm{~m}$ & $7,00 \mathrm{~m}$ & $7,00 \mathrm{~m}$ \\
\hline Largura das calçadas & $3,50 \mathrm{~m}$ & $1,50 \mathrm{~m}$ & $1,50 \mathrm{~m}$ \\
\hline Extensão linear de v & $4,67 \mathrm{Km}$ & $3,32 \mathrm{Km}$ & $1,05 \mathrm{Km}$ \\
\hline
\end{tabular}

Fonte: Elaboração dos autores, a partir de Projetos e Convenções (M+M ARQUITETURA \& DESIGN, 2017, [on-line]).

Dentre os três condomínios estudados, o Condomínio Cidade Jardim I se destaca pelo número de quadras e lotes em seu espaço interno. Quanto à área média dos lotes, o Condomínio Cidade Jardim I e o Condomínio Greenville Exclusive encontram-se bastante equilibrados, o que reflete em parte o momento econômico similar da época em que foram lançados, com redução importante dos lotes e acréscimo em quantidade com relação ao que se verifica no Condomínio Greenville I. Dado o reduzido tamanho de gleba em que foi construído o Condomínio Greenville Exclusive, em virtude da diminuição de grandes glebas vazias com preços atrativos lindeiras à Av. Augusto Montenegro em seu período de lançamento, as características desse condomínio são em geral de números inferiores aos demais estudados. 
Rios, M. F. G; Lima, J. J. F.

Quadro 2: Equipamentos, itens de lazer e lotes comerciais nos condomínios estudados.

\begin{tabular}{|l|c|c|c|}
\hline \multicolumn{1}{|c|}{ ITEM } & GREENVILLE I & $\begin{array}{c}\text { CIDADE } \\
\text { JARDIM I }\end{array}$ & $\begin{array}{c}\text { GREENVILLE } \\
\text { EXCLUSIVE }\end{array}$ \\
\hline Academia de ginástica & $\mathrm{X}$ & & $\mathrm{X}$ \\
\hline Churrasqueira & $\mathrm{X}$ & $\mathrm{X}$ & $\mathrm{X}$ \\
\hline Lotes comerciais & $\mathrm{X}$ & $\mathrm{X}$ & $\mathrm{X}$ \\
\hline Piscinas adulto e infantil & $\mathrm{X}$ & $\mathrm{X}$ & $\mathrm{X}$ \\
\hline Playground infantil & & $\mathrm{X}$ & $\mathrm{X}$ \\
\hline Praças & $\mathrm{X}$ & & $\mathrm{X}$ \\
\hline Quadra de areia & $\mathrm{X}$ & & $\mathrm{X}$ \\
\hline Quadra de tênis & $\mathrm{X}$ & & $\mathrm{X}$ \\
\hline Quadra de voley & $\mathrm{X}$ & $\mathrm{X}$ & $\mathrm{X}$ \\
\hline Quadra poliesportiva & & & $\mathrm{X}$ \\
\hline Quiosque com churrasqueira & & & $\mathrm{X}$ \\
\hline Quiosques & & $\mathrm{X}$ & \\
\hline Salão de festas & & $\mathrm{X}$ & \\
\hline
\end{tabular}

Fonte: Elaboração dos autores, a partir de Projetos e Convenções (M+M ARQUITETURA \& DESIGN, 2017, [on-line]).

Conforme demonstrado no Quadro 2 e Gráfico 6, observam-se quanto à capilaridade números superiores do Condomínio Cidade Jardim I em relação aos demais, o que pode ser explicado pelo desenho irregular de sua gleba, que acaba obrigando à criação de uma quantidade maior de vias internas, de forma a se obter um maior rendimento no desmembramento dos lotes habitacionais. Pelo menor desmembramento de seus lotes, apesar da característica também irregular de sua gleba, o Condomínio Greenville I conseguiu alcançar maior racionalidade neste item.

Quanto à compacidade, é possível perceber valores aproximados entre o Condomínio Cidade Jardim I e o Condomínio Greenville Exclusive, ambos com números superiores em relação ao Condomínio Greenville I. A distinção do momento econômico em que cada condomínio foi construído fica evidente na medida em que se percebe a busca pelo fracionamento cada vez maior dos lotes dos Condomínios Cidade Jardim I e Greenville Exclusive, de dimensões médias de $9 \times 20 \mathrm{~m}$ e $10 \times 20 \mathrm{~m}$, voltados naquele momento a atender as demandas da classe média, ao contrário do que pretendia o empreendedor do Condomínio Greenville I, que num momento anterior, início dos anos 1990, direcionava seu público alvo às classes de alta renda, fracionando sua gleba em quantidades bem menores de lotes, porém, com dimensões que variavam de $15 \times 32 \mathrm{~m}$ até 30 x $32 \mathrm{~m}$.

Gráficos 1, 2, 3, 4: Relação de lotes, quadras, áreas e extensão de vias dos empreendimentos.

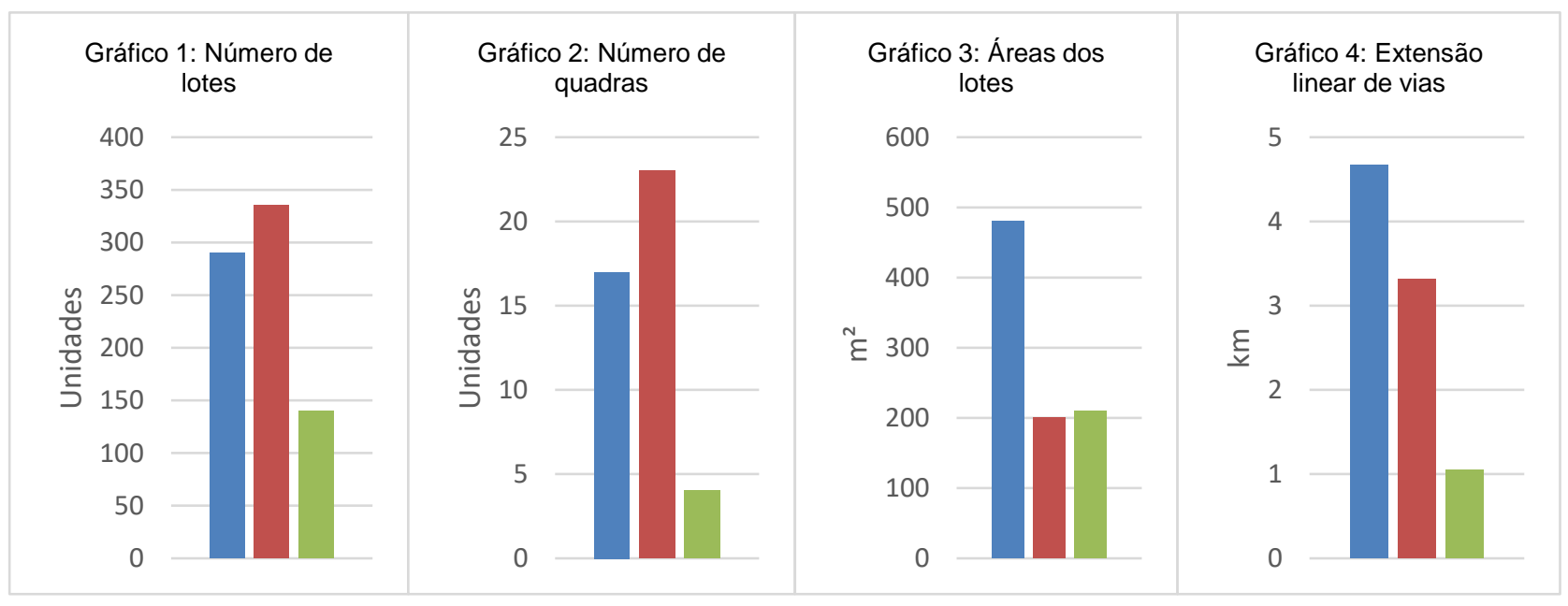

Fonte: Elaboração dos autores, a partir de Projetos e Convenções (M+M ARQUITETURA \& DESIGN, 2017, [on-line]). 
Gráfico 6: Racionalidade econômica dos empreendimentos (capilaridade /compacidade /permeabilidade).
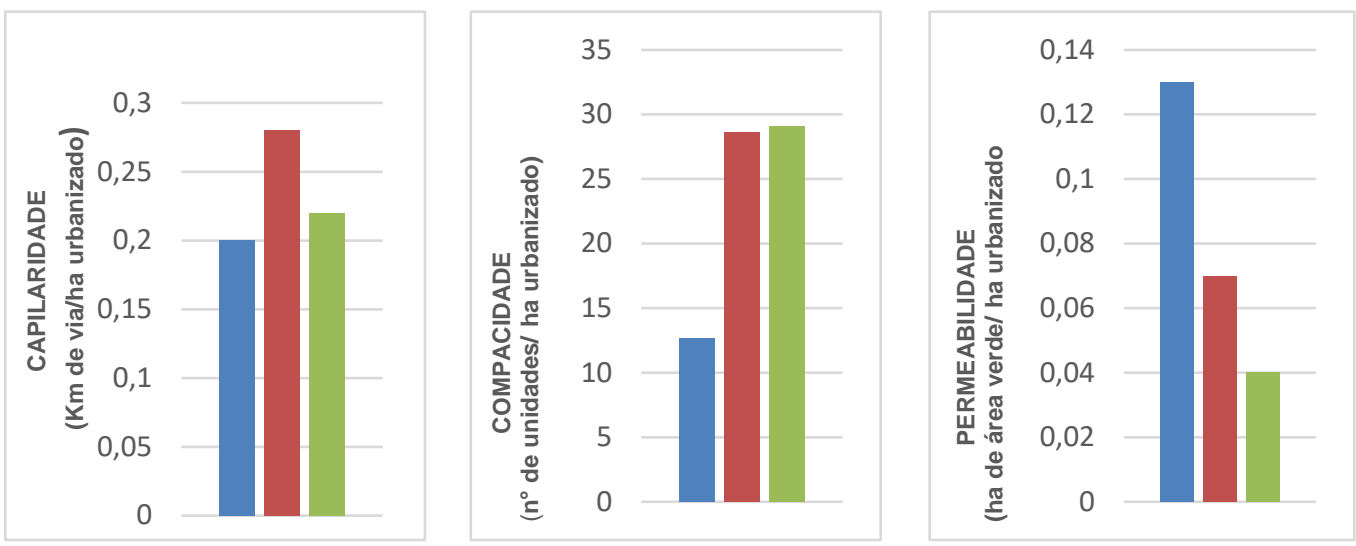

Fonte: Elaboração dos autores, a partir de Projetos e Convenções (M+M ARQUITETURA \& DESIGN, 2017, [on-line]).

Quanto à permeabilidade, o Condomínio Greenville I apresenta valores superiores, pelo próprio conceito vigente no final da década de 1990, conforme tratado no início deste trabalho. Os valores de permeabilidade na sua execução revelam que, além da busca do empreendedor por um condomínio de alto padrão quanto à segurança e à qualidade de vida, buscou mais áreas livres e de lazer, tendo inclusive contado com a participação do paisagista Burle Marx na definição do arvoredo e de extensas áreas verdes distribuídas no interior do condomínio. O condomínio possui canteiro central de $2 \mathrm{~m}$ de largura ao longo da via de acesso principal, além de lotes cujas dimensões possibilitaram - e cujas regulações promoveram - a criação de áreas verdes. Neste item, o Condomínio Greenville Exclusive apresentou maior racionalidade econômica, com a utilização de grande parte de sua gleba - muito reduzida em relação as demais - ao desmembramento de lotes A acionais.

O fato de sua configuração urbanística tornar o Condomínio Greenville I aquele mais permeável entre os estudados é, no entanto, o menos racional economicamente. O que faz refletir acerca da contradição criada por este parâmetro, já que a presença de áreas verdes no espaço intramuros foi item de grande apreço por parte dos compradores de alta renda, como forma de valorização do imóvel e pela própria característica herdada historicamente, que tem como essencial e símbolo da qualidade de vida a existência de arvoredo e grandes áreas verdes nos espaços condominiais fechados horizontais. Assim, apesar de o Condomínio Greenville I ter alcançado o pior desempenho quanto à racionalidade econômica evidenciada no item permeabilidade, a lógica mercadológica cria, através da implantação de áreas verdes, dentre outros fatores, uma espécie de valor agregado ao imóvel e, portanto, ao seu preço final de venda, obtendo, na verdade, uma valorização econômica pela implantação de áreas verdes em lotes onde poderiam ser construídas unidades habitacionais.

Sobre o entorno em que os condomínios foram inseridos, cabe a análise comparativa dos resultados que as morfologias geraram relativamente ao que é encontrado no entorno de bairro. Para uma comparação, tomouse um conjunto de dados do bairro Parque Verde, onde estão localizados os condomínios, para correlação da compacidade e valores de densidade demográfica. Mediante informações obtidas do Anuário Estatístico do Município de Belém de 2012 (BELÉM, 2012), foi possível a composição do quadro abaixo.

Quadro 3: Dados de compacidade e densidade dos condomínios em estudo e do bairro Parque Verde, em 2012.

\begin{tabular}{|l|c|c|c|c|}
\hline \multicolumn{1}{|c|}{ ITEM } & GREENVILLE I & $\begin{array}{c}\text { CIDADE } \\
\text { JARDIM I }\end{array}$ & $\begin{array}{c}\text { GREENVILLE } \\
\text { EXCLUSIVE }\end{array}$ & $\begin{array}{c}\text { BAIRRO } \\
\text { PARQUE VERDE (1) }\end{array}$ \\
\hline $\mathrm{N}^{\circ}$ de lotes & 290 & 335 & 140 & 10.767 \\
\hline $\mathrm{N}^{\circ}$ estimado de habitantes & 1053 & 1216 & 508 & 39.112 \\
\hline Área total (ha) & 22,911 & 11,698 & 4,806 & 509,68 \\
\hline $\begin{array}{l}\text { Compacidade ( }{ }^{\circ} \text { de unidades/ha } \\
\text { urbanizado) }\end{array}$ & 12,65 & 28,64 & 29,13 & 21,13 \\
\hline $\begin{array}{l}\text { Densidade demográfica } \\
\text { (habitantes / ha) }\end{array}$ & 45,96 & 103,95 & 105,70 & 76,77 \\
\hline \multicolumn{2}{|r|}{} \\
\hline
\end{tabular}

Fonte: Elaboração dos autores, a partir de Projetos e Convenções (M+M ARQUITETURA \& DESIGN, 2017, [on-line]) e do Anuário Estatístico do Município de Belém (BELÉM, 2012).

De acordo com as informações do Anuário estatístico de Belém (BELÉM, 2012), o bairro Parque Verde possui 509, 68 hectares de extensão e população residente de 39.126 habitantes. Tem-se, desta forma, densidade 
demográfica de 76,77 no bairro. Para o cálculo de número de unidades existentes no bairro, foram utilizados os dados do número de domicílios particulares permanentes, por situação de domicílio, originalmente obtidos pelo IBGE (2010) e constante em Belém (2012), em que se pôde aferir a existência de 10.767 domicílios, uma compacidade de 21,13 no bairro Parque Verde. Apesar de não ser um indicador detalhado a ponto de incluir pormenores das morfologias do bairro, há de se considerar que, em 2012, passados cerca de dez anos após a implantação dos condomínios, há alterações no sentido de se transformar o Parque Verde em um bairro de condomínios fechados em Belém. Isso pode ser ainda comprovado pela definição de uma das zonas de uso e ocupação prevista no Plano Diretor de 2008 (BELÉM, 2008) (Figura 1).

Os condomínios objetos de estudo estão inseridos na Zona do Ambiente Urbano 6 (ZAU6), setor IV e modelo 1 , que se aplica para lotes acima de $125 \mathrm{~m}^{2}$. Vale ressaltar que não é permitido o parcelamento de lotes acima de $360 \mathrm{~m}^{2}$ para esta zona, informação que constata a inviabilidade, segundo a legislação urbanística da cidade aberta, do parcelamento existente no Condomínio Greenville I, com lotes a partir de $480 \mathrm{~m}^{2}$.

Como critério para definição do número de habitantes por domicílio nos espaços intramuros, utilizou-se a relação habitantes (39.112 hab.) por domicílio (10.767 dom.) no bairro Parque Verde (BELÉM, 2012), com resultado de 3,63 hab/domicílio. Este dado foi utilizado, assim, para a definição de número de habitantes em cada condomínio e posterior quantificação das densidades demográficas dos condomínios.

Gráfico 7: Gráficos comparativos de compacidade e densidade demográfica dos condomínios e do bairro Parque Verde

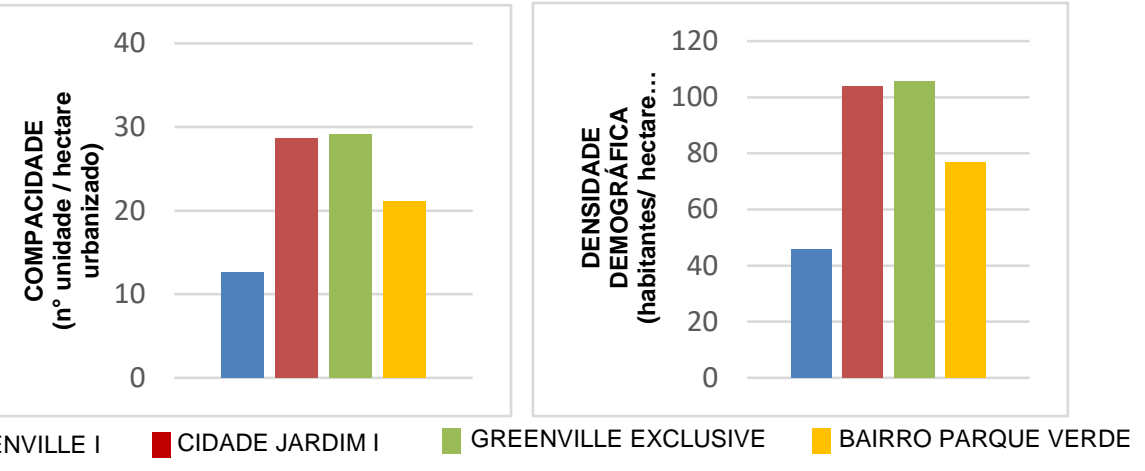

Fonte: Elaboração dos autores, a partir de Projetos e Convenções (M+M ARQUITETURA \& DESIGN, 2017, [on-line]) e do Anuário Estatístico do Município de Belém (BELÉM, 2012).

Verifica-se que a configuração dos Condomínios Cidade Jardim I e Greenville Exclusive gerou espaços edificados mais compactos e consequentemente mais densos do que os encontrados em seu entorno de bairro, o que reflete a dinâmica econômica adotada pelo mercado imobiliário pós-anos 2000 como consequência de um novo cenário nacional que se apresentava, através do desmembramento acentuado de lotes nos espaços intramuros, em atendimento à demanda da classe média, que cada vez mais buscava espaços residenciais fechados na área de expansão da cidade. Como contraponto, diante da realidade econômica vivida no início dos anos 1990 e do atendimento da demanda oriunda da alta renda local, o Condomínio Greenville I teve seu espaço interno menos compacto e menos denso em relação ao encontrado no bairro em 2012 - mediante dados de Belém (2012) -, primando por amplas dimensões de lotes e de extensões de áreas verdes.

\section{As casas dos condomínios}

A análise de locação nos lotes e planta baixa de casas considera os parâmetros reguladores impostos pelas convenções condominiais, como recuos obrigatórios, altura máxima permitida, projeção horizontal e diretrizes a ordenar também a construção de abrigos de automóveis e edículas. Assim, é ação de grande valia como forma de se buscar reconhecer em suas características e relações espaciais, os efeitos de tais parâmetros na definição das tipologias residenciais. No Quadro 4, são apresentados os parâmetros construtivos internos dos condomínios estudados, e no Quadro 5 há representação da aplicação dos mesmos em lotes de dimensão padrão de cada condomínio, bem como suas representações gráficas.

Após o fechamento dos muros, registro em cartório do estatuto social e da convenção condominial, os empreendimentos passam a ser regidos por normas e orientações próprias bem específicas. Além de uma espécie de código de posturas que determinará condutas quanto ao "bem viver", de modo que a convenção condominial e o regimento interno trarão determinações quanto à execução de suas edificações, em analogia à lei de uso e ocupação do solo e ao Código Civil, vigente na cidade "aberta". 
A análise das restrições aplicadas aos lotes edificados torna possível observar distinções entre as determinantes de uso do solo dos condomínios lançados ainda nos anos 90 e daqueles lançados a partir dos anos 2000. No Condomínio Greenville I, lançado nos anos 1990, constata-se que, apesar de suas dimensões de lotes consideráveis, estabeleceu-se em seus regimentos internos uma permissividade construtiva bem menor em relações aos condomínios lançados após 2000. O Condomínio Greenville I traz o parâmetro "projeção horizontal", limitando a ocupação do lote à metade de sua área total, o que nos permite verificar a preocupação do incorporador e posteriormente da "sociedade" de moradores com o conforto ambiental, gerado pela fluidez dos ventos entre as casas, além de recuos laterais obrigatórios, configurando um espaço de pouca compacidade edilícia e boa permeabilidade do solo.

Quadro 4: Parâmetros construtivos previstos nas convenções condominiais aplicáveis aos lotes dos empreendimentos.

\begin{tabular}{|c|c|c|c|}
\hline PARÁMETROS & GREENVILLE I & CIDADE JARDIM I & GREENVILLE EXCLUSIVE \\
\hline Recuo frontal & $\begin{array}{l}\text { 3,00 m (projeções) } \\
4,00 \mathrm{~m} \text { (paredes) }\end{array}$ & $\begin{array}{l}2,00 \mathrm{~m} \text { (lote residencial) } \\
0,00 \text { m (lote não residencial) }\end{array}$ & $\begin{array}{l}2,00 \mathrm{~m} \text { (lote residencial) } \\
5,00 \mathrm{~m} \text { (lote não residencial) }\end{array}$ \\
\hline Recuo lateral & $\begin{array}{l}\text { 1,00 m (projeção dos telhados) } \\
1,50 \mathrm{~m} \text { (sacadas e paredes) }\end{array}$ & $\begin{array}{l}0,00 \mathrm{~m} \text { ((lotes residenciais e não } \\
\text { residenciais) } \\
1,00 \mathrm{~m} \text { (muro do condomínio) } \\
\end{array}$ & $\begin{array}{l}0,00 \mathrm{~m} \text { ((lotes residenciais e não } \\
\text { residenciais) } \\
1,00 \mathrm{~m} \text { (muro do condomínio.) }\end{array}$ \\
\hline Recuo fundos & $\begin{array}{l}2,00 \mathrm{~m} \text { (projeção do telhado e } \\
\text { sacadas) } \\
3,00 \mathrm{~m} \text { (paredes e pilares) }\end{array}$ & $\begin{array}{l}0,00 \mathrm{~m} \text { (lotes residenciais e não } \\
\text { residenciais) } \\
1,00 \mathrm{~m} \text { (muro do condomínio) } \\
\end{array}$ & $\begin{array}{l}0,00 \mathrm{~m} \text { (lote residencial) } \\
1,50 \mathrm{~m} \text { (lote não residencial) }\end{array}$ \\
\hline Altura máxima & $10,00 \mathrm{~m}$ & $\begin{array}{l}10,00 \mathrm{~m} \text { (lote residencial) } \\
20,00 \mathrm{~m} \text { (lote não residencial) }\end{array}$ & $\begin{array}{l}10,00 \text { m (lotes residenciais e não } \\
\text { residenciais) }\end{array}$ \\
\hline Projeção horizontal & $\begin{array}{l}50 \% \text { incluindo construção } \\
\text { principal + edícula }\end{array}$ & Não mencionado & Não mencionado \\
\hline Abrigo automóveis & $\begin{array}{l}\text { 7,00 (extensão numa lateral) } \\
\text { 3,00 (altura máxima) }\end{array}$ & Não mencionado & Não mencionado \\
\hline Edícula & $\begin{array}{l}\text { Permitida nos fundos do terreno; } \\
\text { Altura máxima: } 4,00 \mathrm{~m} \text {; } \\
\text { Afastamento da constr. principal: } \\
3,00 \mathrm{~m} \text {; } \\
\text { Permitido encontrar numa lateral } \\
\text { até } 7,00 \mathrm{~m} \text { de extensão }\end{array}$ & Não mencionado & Não mencionado \\
\hline Divisão entre lotes & $\begin{array}{l}\text { Gradil de ferro e tela de arame } \\
\text { até a altura de } 2,00 \mathrm{~m}\end{array}$ & $\begin{array}{l}\text { Muro, mureta ou alambrado } \\
\text { divisório até a altura de } 2,00 \mathrm{~m}\end{array}$ & $\begin{array}{l}\text { Muro, mureta ou alambrado } \\
\text { divisório até a altura de } 2,00 \mathrm{~m}\end{array}$ \\
\hline
\end{tabular}

Fonte: Elaboração dos autores, a partir de Projetos e Convenções (M+M ARQUITETURA \& DESIGN, 2017, [on-line]) e do Anuário Estatístico do Município de Belém (BELÉM, 2012).

Um elemento específico presente na convenção condominial do Greenville I e tratado com a denominação "edícula", delimita uma espécie de anexo à construção principal, normalmente composta por área de churrasqueira e espaços de serviço, como lavanderia, área de serviço com tanque, um banheiro e dependência. Além disso, não é permitido que a construção principal atinja os limites do terreno, exceção feita ao abrigo de automóveis também passível de regulação. Edículas deverão ser construídas nos fundos do terreno, com possibilidade de uso de uma lateral, limitada a 7,00 m de extensão. A configuração espacial das casas neste condomínio, que toma forma a partir de tais restrições regimentais, gera espaços residenciais que giram em torno de $500 \mathrm{~m}^{2}$.

A separação através de gradis entre os lotes demonstra a busca pela diminuição de barreiras e/ou bloqueios visuais e espaciais, reforçando condições que permitam ainda a fluidez dos ventos almejada na convenção. Elementos físicos, como grades e portões internos aos lotes, não são citados nos instrumentos reguladores, porém, quase inexistem nos arranjos condominiais fechados, dado o aparato de vigilância e segurança muito característico deste tipo de arranjo espacial.

Vale ressaltar que, apesar de os regimentos internos nortearem a execução de obras nos lotes, eles trazem também como pré-requisito para aprovação das construções a anuência dos órgãos reguladores externos, como a Secretaria de Urbanismo (SEURB), na esfera municipal, e Conselhos de classe (CREA/CAU), na esfera federal. Tais órgãos têm livre acesso para fiscalizar, acompanhar e embargar construções executadas de forma ilegal ou irregular no interior do espaço condominial.

As casas dos Condomínios Cidade Jardim I e Greenville Exclusive, que vieram a seguir, já depois dos anos 2000, apresentam princípios de projeto bem diversos das anteriores. A partir de uma nova realidade imobiliária, que demandava o conceito "condomínio fechado horizontal" para um público emergente de classe média, os lotes tiveram suas dimensões reduzidas consideravelmente, fazendo com que os regimentos internos tivessem um caráter muito mais permissivo quanto à ocupação nos lotes. 
Após os anos 2000 os recuos frontais das edificações condominiais foram reduzidos e, nos recuos laterais, passa a ser permitido que se atinja os limites do terreno. Pouco ou nada se almeja quanto à fluidez dos ventos entre as edificações, tornando possível a configuração de um arranjo espacial que se assemelha a vilas de casas geminadas.

Quadro 5: Potenciais construtivos edilícios nos condomínios fechados estudados com a aplicação das restrições construtivas.

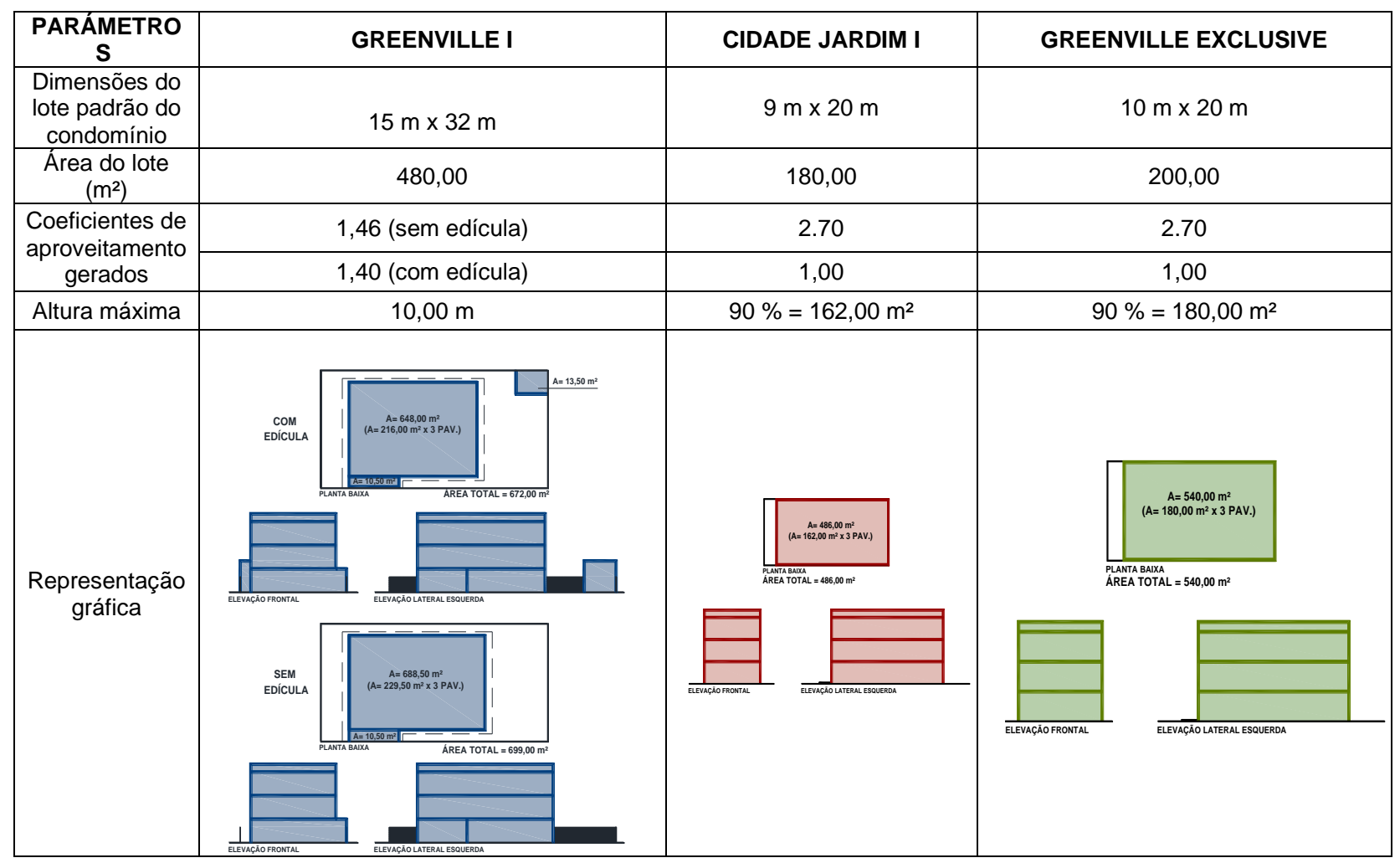

Fonte: Adaptados dos Estatutos e Convenções condominiais dos condomínios Greenville I (1994); Cidade Jardim I (2004); Greenville Exclusive (2008).

Entre lotes, passa a ser permitida ainda a construção de mureta ou alambrado divisório até altura de 2,00m, porém, com liberdade ao proprietário, de deixar seus limites livres ou apenas com "cerca viva". O item "edículas" não é mencionado nos regulamentos desses condomínios, apesar de ser uma edificação de grande ocorrência intralotes. Sua liberdade de execução é sugerida quando não se observa nenhuma limitação quanto ao recuo nos fundos dos lotes. A configuração espacial nos Condomínios Cidade Jardim I e Greenville Exclusive tem gerado residências com área total que varia entre 170,00 $\mathrm{m}^{2}$ e 190,00 m².

Do mesmo modo que ocorre nos residenciais dos anos 90 , estes últimos também contam com a anuência e fiscalização dos órgãos reguladores, momento em que toda a permissividade encontrada no regimento interno desses condomínios sofre restrições próprias ao Código Civil. Um por exemplo disso é o recuo obrigatório lateral de 1,50 m (exceção ao abrigo para automóveis) para abertura de vão de janelas, sacadas e afins (salvo consenso entre moradores extramuros), dentre outros critérios limitadores.

De forma geral, observa-se que as convenções condominiais dos Condomínios Cidade Jardim I e Greenville Exclusive permitem que seus lotes sejam ocupados quase que em sua totalidade, senão pelo recuo frontal obrigatório de 2,00m, enquanto no Condomínio Greenville I, a projeção horizontal exigida de $50 \%$ faz com que se visualizem no interior do lote áreas de vazios ou permeáveis ao redor das edificações. Não há restrição quanto ao coeficiente de aproveitamento, sendo este limitado à altura máxima permitida de $10 \mathrm{~m}$ para os três condomínios analisados.

Considerando o aproveitamento edilício máximo nos tamanhos médios dos lotes condominiais estudados, segundo as restrições construtivas estabelecidas nas convenções, temos áreas totais edificadas que podem chegar a 699,00 $\mathrm{m}^{2}$, no Condomínio Greenville I; 486,00 m², no Condomínio Cidade Jardim I; e 540,00 m², no Condomínio Greenville Exclusive.

Como forma de estabelecer um comparativo do previsto nas regulações internas dos condomínios quanto ao potencial edilício máximo permitido, em relação ao que é preconizado pela regulação pública urbana, mediante diretrizes do Plano Diretor Urbano (PDU) de Belém, teríamos como resultados o que segue no 
Quadro 6. Para efeito de análise, tomou-se como referência um lote fictício de $200,00 \mathrm{~m}^{2}$, com dimensões de $10 \times 20 \mathrm{~m}$, conforme aqueles encontrados nos condomínios. Para o modelo M1 do PDU, restringe-se a taxa de ocupação a $70 \%$ do terreno, o que permitiria $140,00 \mathrm{~m}^{2}$ de ocupação do lote-referência de $200 \mathrm{~m}^{2}$. Dado o coeficiente de aproveitamento permitido de 1.4, chegar-se-ia à área total máxima edificada de $280,00 \mathrm{~m}^{2}$. Fazendo-se uma analogia a um lote do Condomínio Greenville Exclusive, que possui as mesmas dimensões do lote fictício ora estudado, observa-se área total máxima permitida, no lote intramuros, de $540 \mathrm{~m}^{2}$, o que representa o acréscimo no potencial edilício de quase 100\% em relação ao lote pertencente a ZAU6.

Quadro 6: Restrições construtivas e desenho esquemático do potencial edilício de lote conforme o Plano Diretor de Belém.

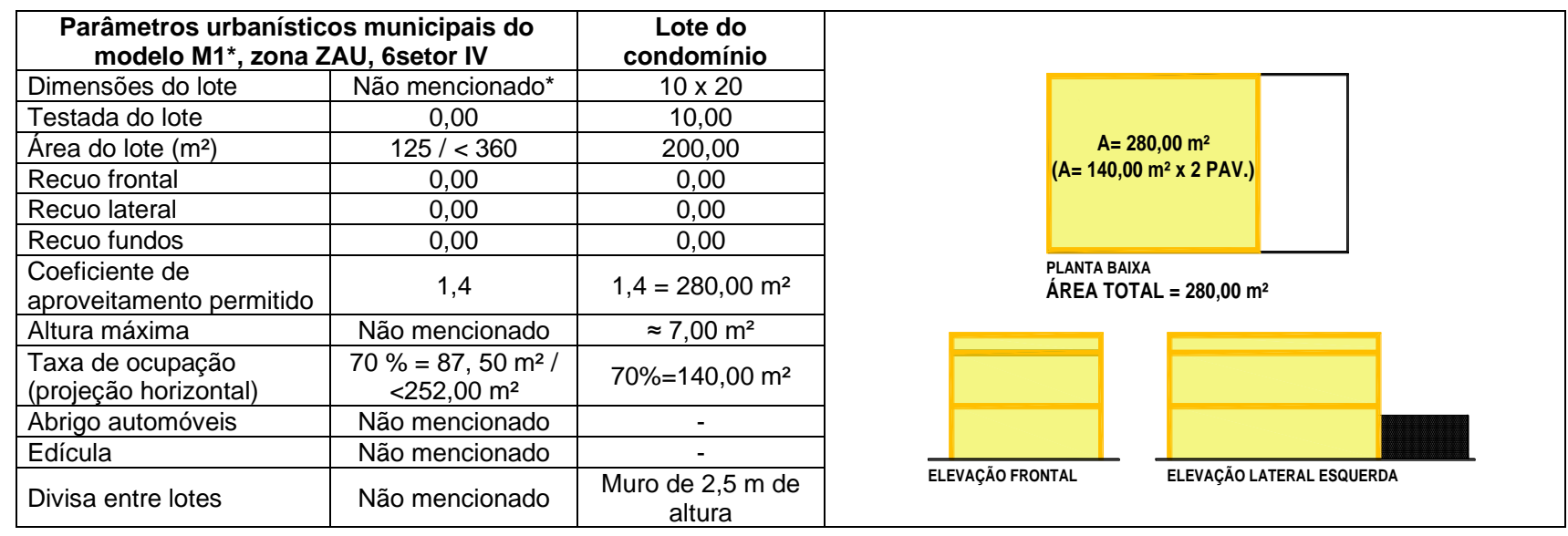

Obs: * Na legislação urbanística do Plano Diretor, o modelo urbanístico se refere ao conjunto de parâmetros urbanísticos composto por tamanhos de recuos, coeficientes, taxas, bem como do tamanho mínimo do lote aplicável por uso e por zona. Neste caso o modelo aplicável não especifica um tamanho de lote mínimo.

Fonte: Adaptado de Belém (2008).

Desta forma, pode-se aferir que as convenções condominiais impõem condições edilícias muito mais permissivas do que as encontradas no regulamento urbanístico da cidade, inclusive viabilizando tamanhos de lotes que não são permitidos perante o código urbano, como os encontrados no Condomínio Greenville I. Apesar de tal constatação, a comparação de potenciais construtivos definidos pelas convenções condominiais e pelo regulamento urbanístico da cidade não reflete na prática o que realmente tem sido realizado quanto à regulação para os projetos das edificações nos espaços intramuros. Para tanto, foram escolhidos para comparação três projetos residenciais de tipologias recorrentes, construídos nos condomínios em estudo, demonstrado nas figuras 2, 3 e 4 e no Quadro 7 a seguir.

A residência do Condomínio Greenville I (Figura 2) está localizada nas proximidades do acesso principal do condomínio, erguida num terreno de $15 \mathrm{~m} \times 32 \mathrm{~m}$, no ano de 1992. Apesar de o coeficiente de aproveitamento gerado pela convenção condominial ser de até 1.4, esta tipologia chegou ao coeficiente de 0.90 de aproveitamento do lote. Já a projeção horizontal encontra-se bem próxima do limite, com $49 \%$ de ocupação.

Figura 2: Plantas baixas de edificação construída no lote 07 da quadra 10 do Condomínio Greenville I.
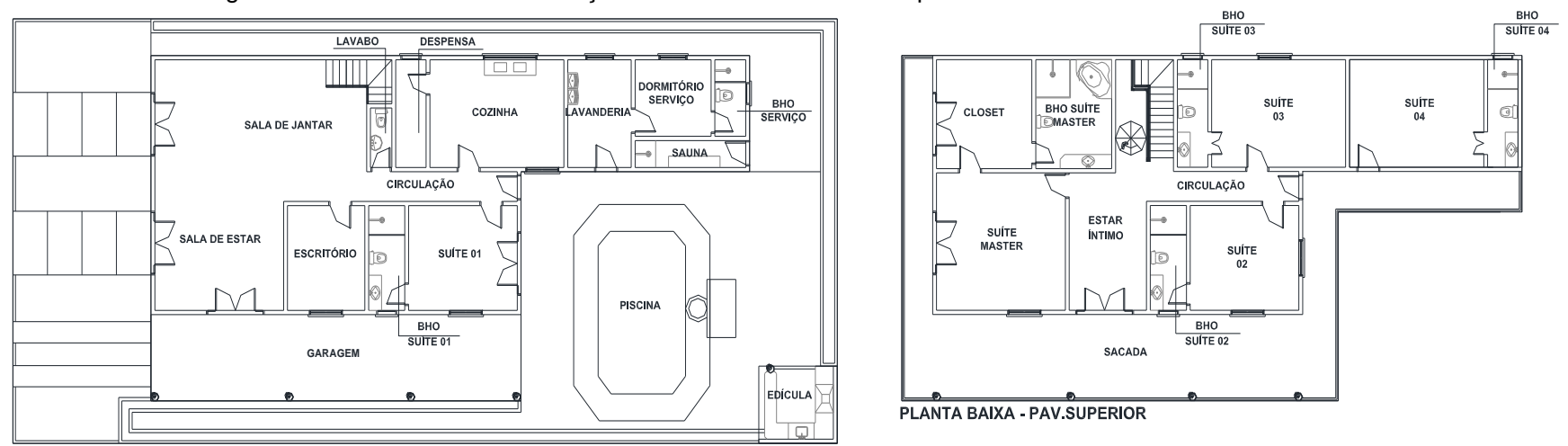

PLANTA BAIXA - PAV.TÉRREO

Fonte: Adaptado pelos autores a partir de M+M Arquitetura \& Design (2017).

A construtora do Condomínio Cidade Jardim I (Figura 3), quando da sua comercialização, oferecia a opção aos futuros proprietários de comprar apenas o lote vazio ou já com a casa executada. O exemplar escolhido 
para este lote é recorrente em cerca de $37 \%$ das edificações encontradas neste condomínio. Já com acréscimo de área construída em relação ao modelo original, a residência está contida num terreno de $9 \mathrm{~m} x$ $20 \mathrm{~m}$, podendo-se observar que, apesar de uma nítida maior utilização do lote, em relação ao observado no Condomínio Greenville I, os resultados obtidos quanto ao coeficiente de aproveitamento (1.09) e projeção horizontal (68\%) ainda estão bem aquém dos permitidos pelas convenções: 2.7 (coeficiente de aproveitamento) e 90\% (projeção horizontal), demonstrando que, apesar da permissividade gerada por tais convenções, os proprietários de classe média só utilizam pequena parte do potencial construtivo de seus lotes. A residência tem área total edificada de 195,69 $\mathrm{m}^{2}$, bem distante dos $486,00 \mathrm{~m}^{2}$ permitidos pela convenção condominial.

Figura 3: Plantas baixas de residência construída no lote 05 da quadra 04 do Condomínio Cidade Jardim I.
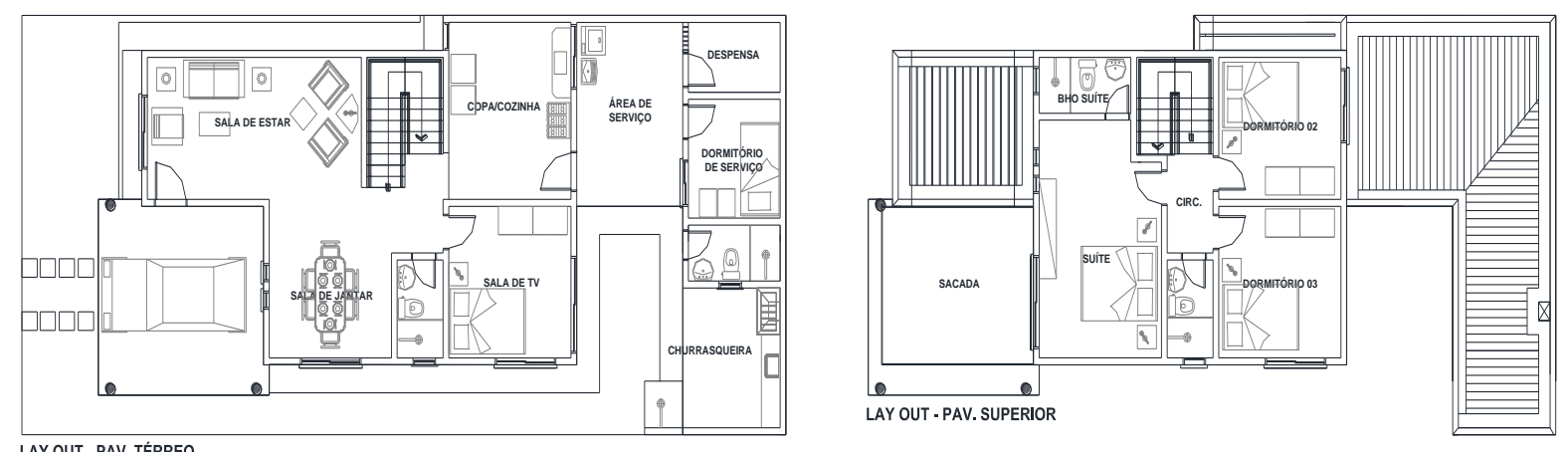

Fonte: Adaptado pelos autores a partir de M+M Arquitetura \& Design (2017).

O Condomínio Greenville Exclusive, de 2006, trouxe a particularidade de vendas de seus lotes já com todas as casas prontas. Diante da mudança tecnológica, com a introdução do bloco estrutural, os empreendedores tiveram como estratégia para potencializar lucros o desenvolvimento de uma linha de casas moduladas à nova tecnologia estrutural, com modelos que melhor se adequariam às necessidades dos futuros moradores ou à demanda criada pelo mercado. São modelos que partiam de duas conformações básicas térreas (matrizes), que geravam, através de três variações de pavimento superior, oito modelos modulados, sendo demonstrada uma das variações na Figura 4.

Figura 4: Plantas baixas de residência construída no lote 13 da quadra 01 Condomínio Greenville Exclusive
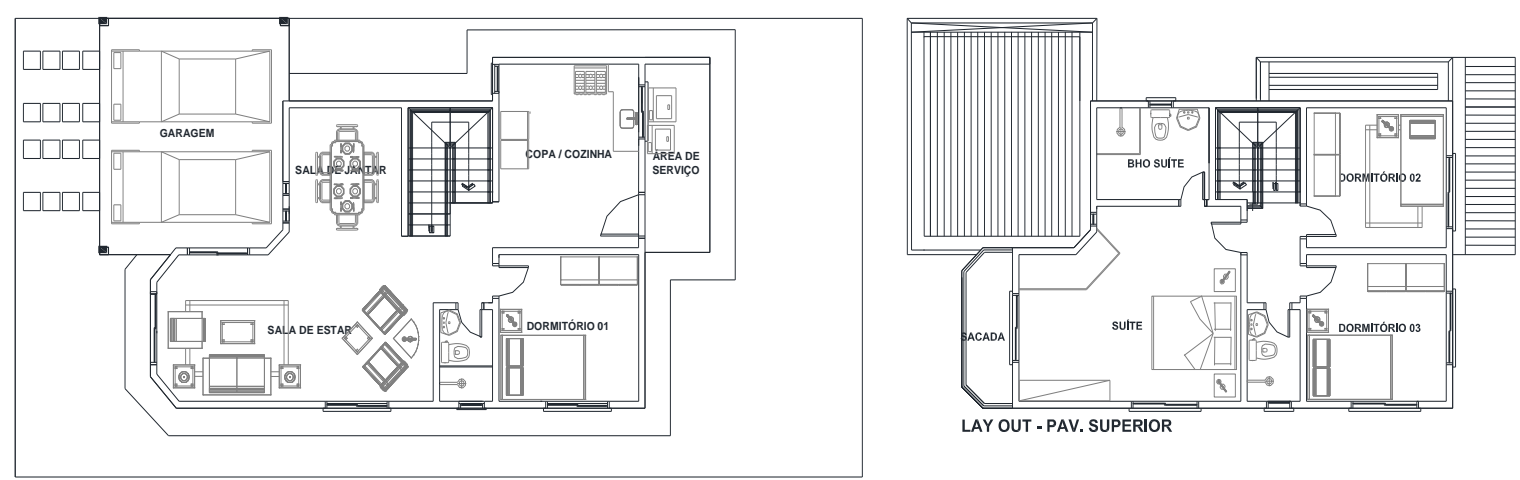

LAY OUT - PAV. TÉRREO

Fonte: Adaptado pelos autores a partir de M+M Arquitetura \& Design (2017).

A distribuição interna desta edificação é muito similar à residência analisada no Condomínio Cidade Jardim I, porém, sem as ampliações realizadas. Apesar da permissividade construtiva de $540,00 \mathrm{~m}^{2}$ para este condomínio, a área total construída desta residência é de apenas $167,66 \mathrm{~m}^{2}$. Como consequência da natureza do capital imobiliário em suas estratégias expansionistas, a partir de 2003 até por volta de 2006, buscou-se a redução dos custos de produção. Desta forma, o mercado imobiliário voltado à execução de condomínios fechados horizontais encontrou uma solução através da substituição de importações de materiais de construção, além de alterações tecnológicas na execução de obras. Em meio às distintas tipologias de habitação, comércio e serviços, dispostos na Av. Augusto Montenegro, surgiam fábricas de blocos estruturais de propriedade das próprias construtoras atuantes, para a construção de seus próprios empreendimentos, além da venda "no atacado" desta matéria-prima. Pode-se ponderar que a baixa utilização do lote no Condomínio Greenville Exclusive se deve inicialmente à limitação dos modelos disponibilizados pela construtora em relação à área edificada, que buscava atender ao público-alvo com áreas totais equilibradas, 
de forma a viabilizar da melhor forma o negócio ao empreendedor. Num segundo momento, já depois de as casas serem executadas, o novo método construtivo, utilizado através da adoção do bloco estrutural, de certa forma "engessava" futuras ampliações, impossibilitava abertura de grandes vãos, dentre outras limitações estruturais que foram impostas aos proprietários.

Quadro 7: Aplicação de parâmetros para construção em lotes dos condomínios fechados estudados:

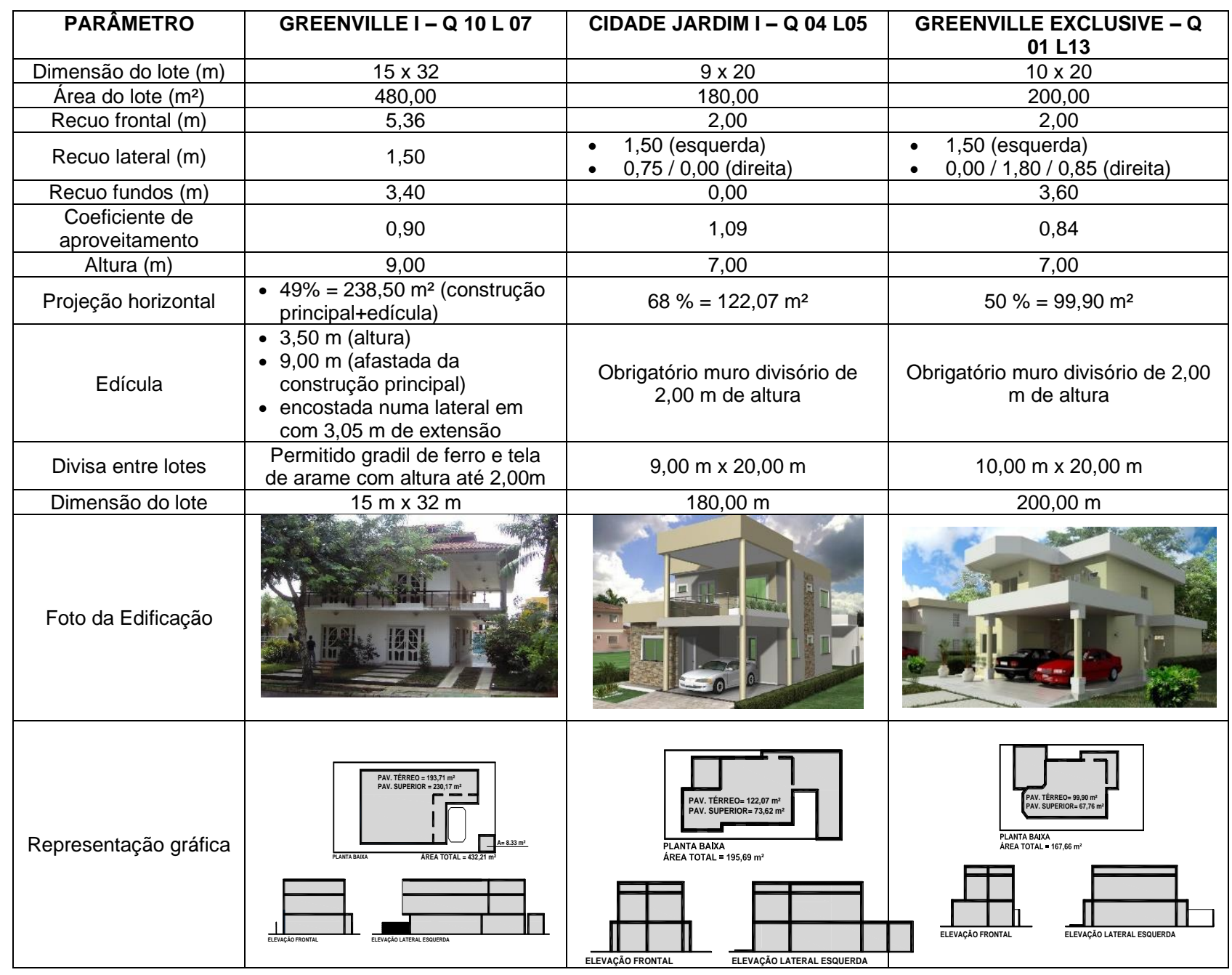

Fonte: Elaboração dos autores, a partir de M+M Arquitetura \& Design (2017).

\section{CONCLUSÃO}

A configuração urbanística dos condomínios fechados horizontais analisados e a tipologia de suas casas sofreram influências significativas dos fatores econômicos vigentes no contexto nacional em que foram construídos, bem como das suas regulações internas (convenções condominiais). Como consequência da falta de um ordenamento jurídico que trate de aspectos relacionados a loteamentos e condomínios de forma plena, o tema "condomínios fechados ou exclusivos" foi conduzido pelos próprios incorporadores no período da construção dos três condomínios fechados analisados, através do estabelecimento de regras próprias na escala urbana. Na comparação entre o que previam as leis federais de condomínios, a de parcelamento, Lei 6766/1979, e depois o Plano Diretor de Belém, verifica-se uma espécie de "mistura" de leis, delas se extraindo o que convém à lógica econômica e do mercado imobiliário, e ignorando aspectos relativos à regulação na esfera pública. Isto é evidenciado na forma como os condomínios resultam de "loteamentos" murados após o lançamento, ou mesmo da aplicação por projetistas, muitas vezes não explícita de parâmetros que já estão de alguma forma previstos nas legislações.

A espacialidade gerada pelo mercado imobiliário através dos condomínios fechados horizontais sob análise traz resultados em que é possível verificar que os condomínios construídos após os anos 2000 foram geradores de padrões de densidade e compacidade superiores aos encontrados no espaço extramuros, ao contrário do que ocorreu no Condomínio Greenville I. Com execução iniciada em 1990 e sob contexto 
econômico diverso, o Condomínio Greenville I, que voltou seu padrão construtivo às altas classes da sociedade, apresentou baixa densidade quando comparado tanto aos demais condomínios quanto ao entorno. Isso também é indicativo de que o entorno, conforme visto no artigo, passa a adotar um padrão de ocupação que difere do condomínio de alto luxo e assemelha-se aos outros dois. Ou seja, as glebas lindeiras à Av. Augusto Montenegro, em que foram instalados os condomínios, geraram um bairro de condomínios de padrões urbanísticos semelhantes. Em 2017, foram contabilizados 23 (vinte e três) condomínios horizontais e 33 (trinta e três) condomínios verticais com acesso direto à Av. Augusto Montenegro.

Quanto aos padrões tipológicos das casas condominiais, a partir da análise de suas convenções observouse grande permissividade construtiva nos Condomínios Cidade Jardim I e Greenville Exclusive em relação ao que é definido pela legislação urbana atualmente vigente. Já o Condomínio Greenville I apresentou condições construtivas bem mais restritivas se comparadas à legislação urbana. Apesar disso, de forma concreta, essa permissividade construtiva verificada nas convenções dos condomínios construídos após os anos 2000 não se refletiu nas casas construídas, que tiveram suas tipologias ditadas muito mais por questões econômicas, mercadológicas e até culturais do que pelo potencial edilício permitido pela regulação interna.

Neste contexto, é plausível ponderar que os projetos arquitetônicos que definiram a configuração interna dos condomínios, bem como a tipologia de suas casas, estão relacionados a uma espécie de "mercadificação" da moradia, gerando conformações espaciais que parecem moldar-se de forma singular aos interesses do capital. Os casos estudados mostram que, sob concepções projetuais conduzidas pelos ditames do mercado, seus agentes "criam" necessidades, desejos e provocam novos hábitos para os consumidores, expondo as inúmeras "facetas" e manobras que o mercado imobiliário crescentemente vem promovendo a partir das décadas de 1990 e 2000, no contexto da Av. Augusto Montenegro, área de expansão de Belém, com a "espacialidade" do capital sob a forma de condomínios fechados horizontais.

\section{REFERÊNCIAS}

\section{BELÉM. Anuário Estatístico do Município de Belém. Prefeitura de Belém, 2012.}

BELÉM. Plano Diretor de Belém: Lei no 8.655/08. Anexos V, X e XI. Belém: Câmara Municipal de Belém, 2008.

BRASIL. Lei 4.591, de 16 de dezembro de 1964. Dispõe sobre o condomínio em edificações e as incorporações imobiliárias. Brasília, D.F.: Presidência da República, [1964].

BRASIL. Lei 6766, de 19 de dezembro de 1979. Dispõe sobre o Parcelamento do Solo Urbano e dá outras Providências. Brasília, D.F.: Presidência da República, [1979].

BRASIL. Lei 9785, de 29 de janeiro de 1999. Altera o Decreto-Lei no 3.365, de 21 de junho de 1941 (desapropriação por utilidade pública) e as Leis nos 6.015, de 31 de dezembro de 1973 (registros públicos) e 6.766, de 19 de dezembro de 1979 (parcelamento do solo urbano). Brasília, D.F.: Presidência da República, [1999].

BRASIL. Lei 13465, de 11 de julho de 2017. Dispõe sobre a regularização fundiária rural e urbana, sobre a liquidação de créditos concedidos aos assentados da reforma agrária e sobre a regularização fundiária no âmbito da Amazônia Legal; institui mecanismos para aprimorar a eficiência dos procedimentos de alienação de imóveis da União; altera as Leis (...) 6.766, de 19 de dezembro de 1979, 10.257, de 10 de julho de 2001 (...); e dá outras providências. Brasília, D.F.: Presidência da República, [2017].

CARDOSO, A. L.; JAENISCH, S. T. Mercado imobiliário e política habitacional nos governos de Lula e Dilma: entre o mercado financeiro e a produção habitacional subsidiada. In: ENCONTRO DA ANPUR, 17. Anais... São Paulo: ANPUR, 2017, s/p.

COMPANHIA DE DESENVOLVIMENTO E ADMINISTRAÇÃO DA ÁREA METROPOLITANA DE BELÉM (CODEM), Cartografia municipal de Belém. CODEM, CD ROM, 2000.

CONDOMÍNIO CIDADE JARDIM I. Convenção condominial. Belém: [s. n.], 2004.

CONDOMÍNIO GREENVILLE EXCLUSIVE. Convenção condominial. Belém: [s. n.], 2008.

CONDOMíNIO GREENVILLE I. Convenção condominial. Belém: [s. n.], 1994.

COSTA, F. N. Financiamento habitacional no Governo Lula. Blog Cidadania \& Cultura, [on-line], 20 fev. 2010. Disponível em: <tinyurl.com/y7bo4gx2>. Acesso em: 20 maio 2020.

CURADO, M. Uma avaliação da economia brasileira no Governo Lula. Revista Economia \& Tecnologia, Curitiba, ano 7 , volume especial, p. 91-103, 2011.

M + M ARQUITETURA \& DESIGN. Acervo digital. M + M Arquitetura \& Design, [on-line], 2017.

MASCARÓ, J. L. Loteamentos urbanos. 2. ed. Porto Alegre: Masquatro, 2005. 
Rios, M. F. G; Lima, J. J. F.

MATTOSO, J.; MUNIZ, S. Habitação - A Habitação no Governo Lula. Fundação Perseu Abramo, [on-line], 23 ago. 2006. Disponível em: <tinyurl.com/y9242dt5>. Acesso em: 20 maio 2020.

MELO, C. A crise cambial brasileira de 1999, a literatura de seus protagonistas e a compreensão do fato. Aurora: Revista de Arte Mídia e Política, São Paulo, n. 6, p. 1-16, 2009.

NETTO, V. M.; SABOYA, R. T. A urgência do planejamento: A revisão dos instrumentos normativos de ocupação urbana. Arquitextos, São Paulo, ano 11, n. 125.02, out. 2010. Disponível em: <tinyurl.com/yaa7saq5>. Acesso em: 20 maio 2020.

SBARRA, M. Quota Ambiental e Taxa de Permeabilidade. Marcelo Sbarra - Arquitetura \& Ensino, [on-line], 6 maio 2018. Disponível em: <tinyurl.com/y715hm6z>. Acesso em: 20 maio 2020.

SOCIEDADE GREENVILLE I. Estatuto social, Regimento interno. Belém: [s.n.], 1994.

SOUZA, E. S. Avaliação de tecnologias ambientais urbanas na Região Metropolitana de Belém-PA. [Relatório Programa PIBIC/UFPa]. Belém: UFPA, 2013.

NOTA DO EDITOR (*): O conteúdo do artigo e as imagens nele publicadas são de responsabilidade do(s) autor(es). 